\title{
PENGARUH KOMPETENSI, MOTIVASI DAN LINGKUNGAN KERJA TERHADAP KINERJA KARYAWAN PDAM TIRTA RANDIK SEKAYU KABUPATEN MUSI BANYUASIN
}

\author{
EFFECT OF COMPETENCE, MOTIVATION AND WORK ENVIRONMENT \\ TOWARD EMPLOYEE PERFORMANCE, PDAM TIRTA RANDIK SEKAYU \\ MUSI BANYUASIN DISTRICT
}

\author{
Ellisyah Mindari \\ STIE Rahmaniyah Sekayu \\ email: ellisyahmindari@gmail.com
}

\begin{abstract}
Abstrak : Penelitian ini bertujuan untuk menguji pengaruh kompetensi, motivasi dan lingkungan kerja terhadap kinerja karyawan PDAM Tirta Randik Sekayu Kabupaten Musi Banyuasin. Penelitian ini menggunakan pendekatan kuantitatif. Dalam penarikan sampel yang peneliti lakukan dengan menggunakan metode slovin. Sampel dalam penelitian ini adalah karyawan PDAM Tirta Randik Sekayu dengan junlah responden sebanyak 76 karyawan. Metode analisis dengan menggunakan alat analisis dengan bantuan program SPSS Versi 17.0. Hasil penelitian ini menunjukan bahwa ada pengaruh yang positif dan signifikan kompetensi, motivasi dan lingkungan kerja secara bersama-sama terhadap kinerja karyawan dengan nilai Fhitung $(45,776)>$ Ftabel $(2,732)$ dan nilai signifikan 0,000. Selanjutnya berdasarkan hasil uji t untuk variabel kompetensi (x1) diperoleh nilai thitung $(0,734)<$ nilai ttabel 1,993, nilai signifikan $t$ sebesar $0,465>$ nilai $\alpha(0,05)$, sehingga dapat disimpulkan bahwa kompetensi (x1) secara parsial tidak berpengaruh secara signifikan terhadap kinerja (Y). Variabel motivasi (x2) diperoleh nilai thitung $(2,743)>$ nilai ttabel (1,993), nilai signifikan $t$ sebesar 0,008 < nilai a $(0,05)$. Dengan hasil tersebut berarti bahwa motivasi (x2) secara parsial berpengaruh positif dan signifikan terhadap kinerja $(Y)$. Sementara itu, hasil uji $t$ untuk variabel lingkungan kerja (x3) dihasilkan nilai thitung $(4,637)>$ nilai ttabel $(1,993)$, nilai signifikan $t$ sebesar $0,000<$ nilai $\alpha$ (0,05). Dari hasil tersebut berarti bahwa lingkungan kerja (x3) secara parsial berpengaruh positif dan signifikan terhadap kinerja $(Y)$.
\end{abstract}

Kata kunci: Kompetensi, Motivasi, Lingkungan Kerja dan Kinerja

Abstract : This study aims to examine the effect of competency, motivation and work environment to employees performance of PDAM Tirta Randik Sekayu, Musi Banyuasin Regency. In this study using a quantitative approach. Sampling in this study uses Slovin method. The sample in this study were 76 employees of PDAM Tirta Randik Sekayu. The analysis method uses an analytical tools with the help of SPSS version 17.0 program. The results of this study indicate that there is a positive and significant effect on competence, motivation and work environment together on employee performance with a value of Fcount (45.776) > Ftable (2.732) and a significant value of 0.000. Furthermore, based on the results of the $t$ 
test for the competency variable (x1) obtained tcount $(0.734)<$ ttable value 1.993 , significant value of $t$ is $0.465>\alpha$ value (0.05), so it can be concluded that competency $(x 1)$ partially has no significant effect on performance $(Y)$. Motivation variable (x2) obtained tcount (2.743) > ttable (1.993), significant value of $t$ was $0.008<\alpha$ value (0.05). With these results it means that motivation ( $x 2$ ) partially has a positive and significant effect on performance $(Y)$. Meanwhile, the results of the t test for work environment variables (x3) produced tcount (4.637) > ttable (1.993), a significant $t$ value of $0.000<\alpha$ value (0.05). From these results it means that the work environment (x3) partially has a positive and significant effect on performance $(Y)$.

\section{Keywords: Competence, Motivation, Work Environment and Performance}

\section{LATAR BELAKANG}

Pembangunan suatu bangsa memerlukan dua aset utama yang disebut sumber daya (resources), yaitu sumber daya alam (natural resources) dan sumber daya manusia (human resources), kedua sumber daya tersebut sangat penting dalam menentukan keberhasilan suatu pembangunan. Sumber daya manusia dapat dilihat dari dua aspek, yakni kuantitas dan kualitas. Kuantitas menyangkut jumlah sumber daya manusia, sedangkan kualitas menyangkut mutu sumber daya manusia.

Semua organisasi, baik itu swasta maupun milik pemerintah mengharapkan karyawan yang dimiliki dapat memberikan kontribusi tenaga dan pikirannya secara maksimal, artinya karyawan dituntut kinerjanya secara optimal atau profesional. Kinerja dipengaruhi oleh banyak faktor, antara lain kompetensi, kompensasi, gaya kepemimpinan, komunikasi interpersonal, motivasi, lingkungan kerja, disiplin kerja, budaya organisasi, diklat, iklim organisasi dan lain sebagainya.

Kompetensi pada umumnya diartikan sebagai kecakapan, kemampuan dan keterampilan. Kata dasarnya kompeten yang berarti cakap, mampu, atau terampil. Pada konteks manajemen sumber daya manusia, istilah kompetensi mengacu kepada atribut atau karateristik seseorang yang membuatnya berhasil dalam pekerjaan. Menurut Andersen dalam Handoko Martin (2003: 152), kompetensi merupakan karakteristik dasar yang terdiri dari kemampuan (skill), pengetahuan (knowledge) serta atribut personal lainnya yang mampu membedakan seseorang yang mempunyai perform dan tidak perform.

Selanjutnya T. Hani Handoko (2003:251) mengemukakan bahwa motivasi merupakan kegiatan yang mengakibatkan, menyalurkan dan memelihara perilaku manusia. Motivasi ini merupakan subyek yang penting bagi manajer karena menurut definisi manajer harus bekerja dengan dan melalui orang lain. Manajer perlu memahami orangorang berperilaku tertentu agar dapat mempengaruhinya untuk bekerja 
sesuai dengan yang diinginkan organisasi. Motivasi adalah juga subyek membingungkan karena motif tidak dapat diamati atau diukur secara langsung, tetapi harus disimpulkan dari perilaku orang yang tampak.

Keberhasilan suatu organisasi dalam mencapai tujuan juga tidak terlepas dari faktor lingkungan kerja. Meskipun faktor tersebut sangat penting, tetapi masih banyak organisasi yang kurang memperhatikan hal tersebut. Anwar Prabu Mangkunegara (2009:17) menyatakan bahwa faktor lingkungan kerja organisasi sangat menunjang bagi individu dalam mencapai kinerja yang optimal. Faktor lingkungan kerja yang dimaksud secara garis besar terbagi menjadi dua bagian yakni lingkungan kerja fisik dan lingkungan kerja non fisik. Lingkungan kerja fisik adalah semua keadaan berbentuk fisik yang terdapat di sekitar tempat kerja yang dapat mempengaruhi karyawan baik secara langsung maupun secara tidak langsung.

Menurut Veithzal Rivai dan Ella Jauvani Sagala (2010:548) kinerja merupakan suatu fungsi dari motivasi dan kemampuan. Di mana setiap individu dalam menjalankan tugas atau pekerjaan sepatutnya memiliki derajat kesediaan dan tingkat kemampuan tertentu. Di samping itu juga harus memiliki motif dalam menjalankan tugas dan pekerjaannya. Oleh karena itu, kemampuan seseorang belumlah cukup efektif untuk mengerjakan pekerjaannya tanpa ada motivasi yang jelas dan dibangun dari pemahaman yang kuat terhadap apa dan bagaimana mengerjakannya serta apa hasilnya jika semuanya dikerjakan dengan baik.

Dari hasil pengamatan yang penulis lakukan terhadap karyawan PDAM Tirta Randik Sekayu Kabupaten Musi Banyuasin, diperoleh informasi bahwa masih adanya karyawan yang bekerja tanpa rencana atau tanpa persiapan yang baik, masih adanya karyawan yang terlambat dan tidak bekerja tanpa alasan yang jelas, masih adanya karyawan yang belum melaksanakan tugas dengan baik, masih adanya karyawan yang kurang merasa memiliki perusahaan tempatnya bekerja, rendahnya kemampuan dan keterampilan karyawan dalam melaksanakan tugas dengan baik, benar dan selesai tepat waktu, masih ada karyawan yang merasa gaji yang mereka terima tidak cukup untuk memenuhi kebutuhan rumah tangganya, kurang kemampuan menerima ide-ide baru, kurangnya komunikasi antar karyawan, karyawan tidak mempunyai target, kurangnya keinginan untuk berkembang dan berprestasi, pelatihan karyawan yang minim juga turut mengurangi motivasi karyawan dalam bekerja, kurangnya keyakinan dalam mendapatkan hasil yang lebih tinggi, kurangnya kesadaran akan pentingnya peningkatan karir, nilainilai atau norama-norma yang ada hanya pedoman tertulis saja, karyawan baru agak sulit beradaptasi dengan karyawan lama, karyawan juga sering mengeluh dengan tidak adilnya pembagian insentif, sehingga mereka agak bermalas-malasan di dalam bekerja serta dalam menjalankan tugas. 
Di samping wawancara dengan karyawan, penulis juga mengamati langsung kondisi lingkungan kerja perusahaan, di mana terlihat penerangan yang kurang baik, ventilasi udara yang kurang baik, tata warna lingkungan kerja yang kurang tepat, adanya unit perusahaan yang berbatasan langsung dengan jalan lintas, sehingga timbul kebisingan dan tata ruang kerja kurang baik.

Dari uraian di atas, maka penulis tertarik untuk membahas secara mendalam melalui penelitian dengan judul pengaruh kompentensi, motivasi dan lingkungan kerja terhadap kinerja karyawan PDAM Tirta Randik Sekayu Kabupaten Musi Banyuasin.

\section{PERUMUSAN MASALAH}

Berdasarkan latar belakang di atas, maka rumusan masalah dalam penelitian ini adalah sebagai berikut:

1. Adakah pengaruh yang positif dan signifikan antara kompetensi, motivasi dan lingkungan kerja secara bersama-sama terhadap kinerja karyawan PDAM Tirta Randik Sekayu Kabupaten Musi Banyuasin?

2. Adakah pengaruh yang positif dan signifikan antara kompentensi, motivasi dan lingkungan kerja secara parsial terhadap kinerja karyawan PDAM Tirta Randik Sekayu Kabupaten Musi Banyuasin?

\section{TUJUAN PENELITIAN}

1. Untuk mengetahui pengaruh kompetensi, motivasi dan lingkungan kerja secara bersamasama terhadap kinerja karyawan PDAM Tirta Randik Sekayu Kabupaten Musi Banyuasin.

2. Untuk mengetahui pengaruh kompetensi, motivasi dan lingkungan kerja secara parsial terhadap knerja karyawan PDAM Tirta Randik Sekayu Kabupaten Musi Banyuasin.

\section{TINJAUAN PUSTAKA}

\section{Kompetensi}

$\begin{array}{cccr} & \text { Veithzal Rivai } & \text { dan Ella } \\ \text { Jauvani } & \text { Sagala } & (2010: 302)\end{array}$ merumuskan definisi kompetensi sebagai kemampuan seseorang yang dapat terobservasi yang mencakup pengetahuan, keterampilan dan sikap dalam menyelesaikan suatu pekerjaan atau tugas sesuai dengan perform yang ditetapkan. Wibowo (2011: 326) kompetensi merupakan kemampuan menjalankan tugas atau pekerjaan dengan dilandasi oleh pengetahuan, keterampilan dan didukung oleh sikap yang menjadi karateristik individu. Penulis mendefinisikan kompetensi adalah kemampuan seseorang dalam menjalankan tugas atau pekerjaannya dengan dilandasi oleh pengetahuan, keterampilan dan didukung oleh sikap yang menjadi karakteristiknya.

\section{$\underline{\text { Motivasi }}$}

Robbins dan Coulter (2010:109) mengemukakan bahwa motivasi mengacu pada proses di mana usaha seseorang diberi energi, diarahkan dan berkelanjutan menuju tercapainya suatu tujuan. Definisi ini memiliki tiga elemen kunci, yaitu 
energi, arah dan ketekunan. Elemen energi adalah ukuran dari intensitas atau dorongan. Seseorang yang termotivasi menunjukkan usaha dan bekerja keras. Namun, kualitas usaha itu juga harus dipertimbangkan, usaha tingkat tinggi tidak selalu mengarah pada kinerja pekerjaan yang menguntungkan kecuali usaha tersebut disalurkan ke arah yang menguntungkan organisasi. Usaha yang diarahkan dan konsisten dengan tujuan organisasi adalah jenis usaha yang kita inginkan dari para karyawan. Akhirnya, motivasi mencakup dimensi ketekunan. Karyawan diharapkan untuk tekun dalam usahanya untuk mencapai tujuan organisasi. Wibowo (2011:379) mendefinisikan motivasi merupakan dorongan terhadap serangkaian proses perilaku manusia pada pencapaian tujuan. Elemen yang terkandung dalam motivasi meliputi unsur membangkitkan, mengarahkan, menjaga, menunjukkan intesitas, bersifat terusmenerus dan adanya tujuan.

Penulis menyimpulkan bahwa motivasi diartikan sebagai suatu proses yang dilakukan seorang karyawan dalam upaya menimbulkan dorongan atau semangat kerja.

\section{Lingkungan Kerja}

Menurut Agus Ahyari (2002:165), lingkungan kerja dalam suatu perusahaan sangat penting untuk diperhatikan oleh manajer perusahaan yang akan mendirikan pabrik untuk perusahaan tersebut. Penyusunan suatu sistem produksi yang baik tidak akan dapat dilaksanakan dengan efektif apabila tidak didukung dengan lingkungan kerja yang memuaskan di dalam perusahaan yang bersangkutan. Menurut Robbins (2001:15), lingkungan kerja adalah sesuatu yang ada di sekitar pekerja dan dapat mempengaruhi dirinya dalam menjalankan tugas-tugas yang dibebankan.

Penulis mendefinisikan lingkungan kerja adalah keadaan di mana tempat kerja yang baik meliputi fisik dan non fisik yang dapat memberikan kesan menyenangkan, aman, tenteram, perasaan betah dan lain sebagainya.

$\begin{array}{lcr} & \text { Kondisi lingkungan kerja di } \\ \text { dalam suatu organisasi sangat } \\ \text { penting untuk diperhatikan. }\end{array}$ Penyusunan suatu sistem yang baik tidak akan dapat dilaksanakan dengan efektif apabila tidak didukung kondisi lingkungan kerja yang baik. Lingkungan kerja yang memuaskan pada akhirnya akan dapat meningkatkan gairah dalam organisasi.

\section{Kinerja}

Pengertian kinerja menurut Rusdy A. Rifai (2009:10) adalah prestasi kerja yang diukur berdasarkan hasil prestasi yang terjadi pada masa lalu yang kemudian ditetapkan sebagai standar untuk mengukur prestasi di masa datang.

Kinerja dipengaruhi oleh variabel individu, variabel organisasi dan variabel psikologis. Variabel individu menyangkut kemampuan individu berupa pendidikan dan keterampilan. Variabel organisasi merupakan variabel yang berhubungan langsung dengan 
kondisi organisasi dan variabel psikologis merupakan variabel yang berhubungan dengan suasana hati dari individu yang bersangkutan. Ketiga variabel tersebut secara dominan akan memberikan pengaruh terhadap kinerja seseorang.

Kinerja menurut penulis adalah hasil kerja secara kualitas dan kuantitas yang dicapai oleh seseorang dalam pelaksanaan tugas sehari-hari sesuai dengan tanggungjawab yang diberikan kepadanya. Jadi untuk mengukur kinerja seseorang dapat dilihat pada situasi dan kondisi kerjanya seharihari.

\section{$\underline{\text { Hipotesis }}$}

1. Ada pengaruh yang positif dan signifikan kompetensi, motivasi dan lingkungan kerja secara bersama-sama terhadap kinerja karyawan PDAM Tirta Randik Sekayu Kabupaten Musi Banyuasin.

2. Ada pengaruh yang positif dan signifkan kompetensi, motivasi dan lingkungan kerja secara parsial terhadap kinerja karyawan PDAM Tirta Randik Sekayu Kabupaten Musi Banyuasin.

\section{$\underline{\text { Kerangka Penelitian }}$}

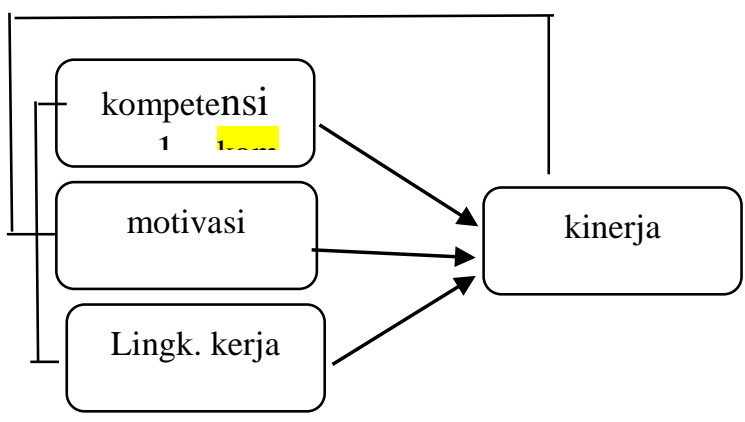

\section{METODOLOGI PENELITIAN}

\section{$\underline{\text { Desain Penelitian }}$}

Menurut tingkat explanasi (level of explanation) atau tingkat penjelasan, jenis penelitian yang penulis lakukan adalah penelitian asosiatif/hubungan. Sugiyono (2007:11) mengemukakan bahwa penelitian asosiatif/hubungan merupakan penelitian yang bertujuan untuk mengetahui hubungan antara dua variabel atau lebih.

\section{$\underline{\text { Populasi dan Sampel }}$}

Sugiyono (2007: 72) mengemukakan bahwa populasi adalah wilayah generalisasi yang terdiri atas objek/subjek yang mempunyai kualitas dan karateristik tertentu yang ditetapkan oleh peneliti untuk dipelajari dan ditarik kesimpulannya. Populasi dalam penelitian ini adalah semua karyawan PDAM Tirta Randik Sekayu berjumlah 316 orang.

Menurut Sugiarto dkk (2003:2), sampel adalah sebagian anggota dari populasi yang dipilih dengan menggunakan prosedur tertentu, sehingga diharapkan dapat mewakili populasinya. Kemudian Sekaran (2006:123) mengemukakan bahwa pengambilan sampel (sampling) adalah proses memilih sejumlah elemen secukupnya dari populasi, sehingga penelitian terhadap sampel dan pemahaman tentang sifat atau karakteristiknya akan membuat kita dapat menggeneralisasikan sifat atau karakteristik tersebut pada elemen populasi. Metode pengambilan sampel yang digunakan adalah 
metode pengambilan sampel bloking (cluster sampling). Selanjutnya Sugiarto dkk (2003:90), mengemukakan bahwa metode pengambilan sampel bloking (cluster sampling) adalah metode yang digunakan untuk memilih sampel yang berupa kelompok dari beberapa kelompok (group atau cluster) dimana setiap kelompok terdiri atas beberapa unit yang lebih kecil (elements).

Dalam penelitian ini populasi dibagi menjadi beberapa kelompok (group atau cluster) yang masingmasing disebut cluster sampel diambil dari setiap cluster secara proposional. Sampel dalam penelitian ini menggunakan metode slovin dengan hasil perhitungan jumlah sampel adalah 76 orang karyawan dari 10 unit kerja PDAM Tirta Randik Sekayu.

\section{PEMBAHASAN}

\section{Uji Regresi Berganda}

Analisis regresi berganda (multiple regression analysis) digunakan untuk melihat besaran pengaruh variabel kompetensi (x1), variabel motivasi (x2) dan variabel lingkungan kerja (x3) terhadap kinerja (Y). Hasil pengolahan data dengan menggunakan SPSS for Windows versi 17.00 ditampilkan dalam tabel sebagai berikut:

\begin{tabular}{|c|c|c|c|c|c|c|}
\hline \multicolumn{7}{|c|}{ Coefficients $^{\mathrm{a}}$} \\
\hline \multirow{2}{*}{\multicolumn{2}{|c|}{ Model }} & \multicolumn{2}{|c|}{ Unstandardized Coefficients } & \multirow{2}{*}{$\begin{array}{c}\begin{array}{c}\text { Standardized } \\
\text { Coefficients }\end{array} \\
\text { Beta }\end{array}$} & \multirow{3}{*}{$\frac{t}{3,342}$} & \multirow{3}{*}{$\frac{\text { Sig. }}{, 001}$} \\
\hline & & B & Std. Error & & & \\
\hline \multirow[t]{4}{*}{1} & (Constant) & 1,016 &, 304 & & & \\
\hline & Kompetensi & ,091 &, 123 & ,099 & ,734 & ,465 \\
\hline & Motivasi & ,217 & ,079 & ,281 & 2,743 & ,008 \\
\hline & Lingk_Kerja & 496 & ,107 &, 522 & 4,637 &, 000 \\
\hline
\end{tabular}

\begin{tabular}{llll}
\multicolumn{1}{c}{$\begin{array}{c}\text { Dari } \\
\text { berganda }\end{array}$} & $\begin{array}{c}\text { hasil } \\
\text { dapat }\end{array}$ & $\begin{array}{l}\text { uji regresi } \\
\text { digambarkan }\end{array}$ & Uji Koefisien Determinan \\
persamaan regresi & bergandanya & Untuk menjawab pengaruh \\
sebagai berikut : & & $\begin{array}{l}\text { kompetensi (x1), motivasi (x2) dan } \\
\text { lingkungan kerja (x3) secara }\end{array}$ \\
$\mathrm{Y}=1,016+0,091 \mathrm{X}_{1}+0,217 \mathrm{X}_{2}+$ & $\begin{array}{l}\text { bersama-sama terhadap kinerja (Y), } \\
0,496 \mathrm{X}_{3}\end{array}$ & $\begin{array}{l}\text { yaitu menggunakan uji koefisien } \\
\text { determinan sebagai berikut : }\end{array}$
\end{tabular}

Model Summary

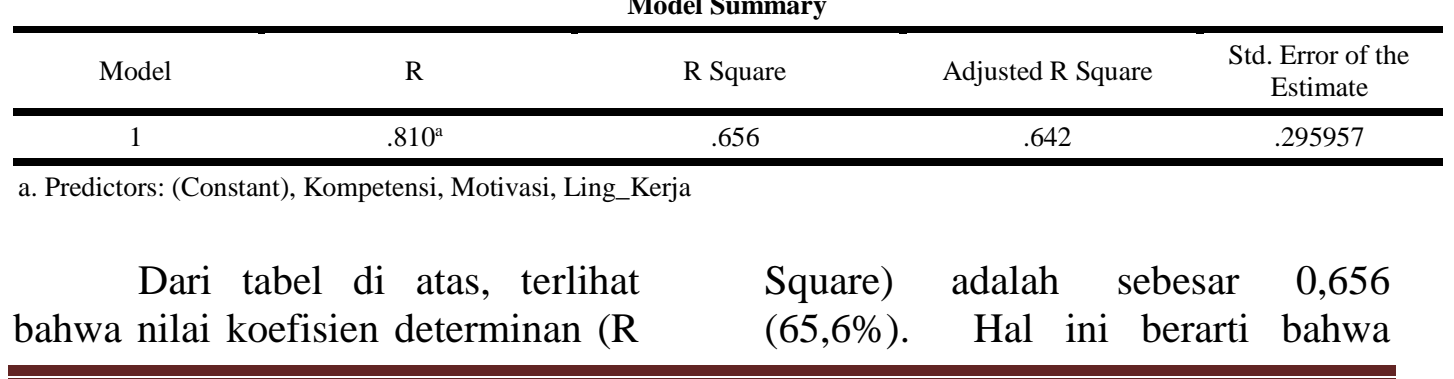


kinerja (Y) dapat dijelaskan oleh kompetensi (x1), motivasi (x2) dan lingkungan kerja (x3) sebesar 65,6\%, sedangkan sisanya $34,4 \%$ dijelaskan oleh faktor lain yang tidak termasuk dalam penelitian ini.

Uji Serentak (uji F)
Untuk menjawab permasalahan tentang bagaimana pengaruh kompetensi (x1), motivasi (x2) dan lingkungan kerja (x3) secara bersama-sama terhadap kinerja (Y), penulis menggunakan uji hipotesis $\mathrm{F}$ sebagai berikut :

\begin{tabular}{llccccc}
\hline & \multicolumn{6}{c}{ ANOVA $^{\mathrm{b}}$} \\
\hline 1 & Model & Sum of Squares & Df & Mean Square & F & Sig. \\
\hline & 12.029 & 3 & 4.010 & 45.776 & $.000^{\mathrm{a}}$ \\
& Residual & 6.307 & 72 & .088 & & \\
Total & 18.335 & 75 & & & \\
\hline
\end{tabular}

a. Predictors: (Constant), Lingk_Kerja, Motivasi, Kompetensi

b. Dependent Variable: Kinerja

Berdasarkan pada di atas, maka dapat dilihat bahwa Fhitung untuk variabel kompetensi (x1), variabel motivasi (x2) dan variabel lingkungan kerja (x3) terhadap kinerja (Y) adalah sebesar 45,776, maka Fhitung $(45,776)>$ Ftabel $(2,732)$ yang berarti bahwa ada pengaruh kompetensi (x1), motivasi (x2) dan lingkungan kerja (x3)secara bersama-sama terhadap kinerja (Y) karyawan PDAM Tirta Randik Sekayu, sehingga H0 ditolak dan Ha diterima.

Nilai signifikan (Sig F) adalah sebesar 0,000 yang berarti Sig
$\mathrm{F}(0,000)<\alpha(0,05)$. Hal tersebut menggambarkan bahwa ada pengaruh yang signifikan kompetensi (x1), motivasi (x2) dan lingkungan kerja (x3) secara bersama-sama terhadap kinerja (Y) karyawan PDAM Tirta Randik Sekayu.

Untuk lebih jelasnya, berikut ini akan penulis sajikan gambar kurva uji $\mathrm{F}$ atas pengaruh kompetensi (x1), motivasi (x2) dan lingkungan kerja (x3) secara bersama-sama terhadap kinerja (Y) adalah sebagai berikut:

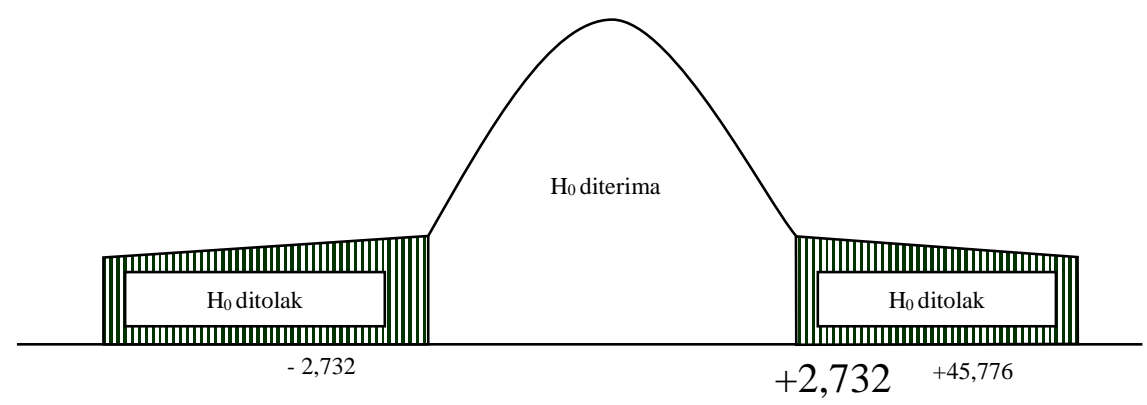


$\underline{\text { Uji Parsial (uji t) }}$

Untuk menjelaskan pengaruh kompetensi (x1), motivasi (x2) dan lingkungan kerja (x3) secara parsial terhadap kinerja (Y), penulis menggunakan uji hipotesis t sebagai berikut :

\section{Coefficients $^{\mathrm{a}}$}

\begin{tabular}{|c|c|c|c|c|c|c|}
\hline \multirow{2}{*}{\multicolumn{2}{|c|}{ Model }} & \multicolumn{2}{|c|}{ Unstandardized Coefficients } & \multirow{2}{*}{$\frac{\begin{array}{c}\text { Standardized } \\
\text { Coefficients }\end{array}}{\text { Beta }}$} & \multirow[b]{2}{*}{$\mathrm{T}$} & \multirow[b]{2}{*}{ Sig. } \\
\hline & & B & Std. Error & & & \\
\hline \multirow[t]{4}{*}{1} & (Constant) & 1,016 & ,304 & & 3,342 & ,001 \\
\hline & Kompetensi & 091 &, 123 & ,099 & ,734 & ,465 \\
\hline & Motivasi & ,217 & ,079 & ,281 & 2,743 & ,008 \\
\hline & LingkunganKerja & ,496 & , 107 &, 522 & 4,637 & 000 \\
\hline
\end{tabular}

Dependent Variable: Kinerja

Menurut Duwi Priyatno (2010:68), jika thitung > ttabel, maka $\mathrm{H} 0$ ditolak dan $\mathrm{Ha}$ diterima, sedangkan jika thitung < ttabel, maka H0 diterima dan Ha ditolak, jika sig $\mathrm{t}$ $>0,05$, maka tidak ada pengaruh yang signifikan dan jika sig $\mathrm{t}<0,05$, maka data tersebut ada pengaruh yang signifikan. Nilai ttabel dengan taraf nyata $(\alpha)=5 \%$, df $=(n-2)=$ (76-2) adalah sebesar $+1,993$, maka:

1. Pengaruh Kompetensi (x1) terhadap Kinerja (Y)

Nilai thitung untuk variabel kompetensi (x1) terhadap kinerja (Y) adalah sebesar 0,734 , maka thitung $(0,734)<$ ttabel $(1,993)$ yang berarti bahwa tidak ada pengaruh kompetensi (x1) secara parsial terhadap kinerja (Y) karyawan PDAM Tirta Randik Sekayu, maka H0 diterima dan Ha ditolak.

Nilai signifikan (Sig t) pengaruh kompetensi (x1) secara parsial terhadap kinerja (Y) adalah sebesar 0,465 yang berarti Sig t $(0,465)>\alpha(0,05)$. Hal tersebut berarti bahwa tidak ada pengaruh yang signifikan kompetensi (x1) secara parsial terhadap kinerja (Y) karyawan PDAM Tirta Randik Sekayu.

2. Pengaruh Motivasi (x2) terhadap Kinerja (Y)

Nilai thitung untuk variabel motivasi (x2) terhadap kinerja (Y) adalah sebesar 2,743, maka thitung $(2,743)>$ ttabel $(1,993)$ yang berarti bahwa ada pengaruh motivasi (x2) secara parsial terhadap kinerja (Y) karyawan PDAM Tirta Randik Sekayu, maka H0 ditolak dan $\mathrm{Ha}$ diterima.

Nilai signifikan $(\mathrm{Sig} \quad \mathrm{t})$ pengaruh motivasi (x2) secara parsial terhadap kinerja $(\mathrm{Y})$ adalah sebesar 0,008 yang berarti Sig $t(0,008)<\alpha$ $(0,05)$. Hal tersebut berarti bahwa ada pengaruh yang signifikan motivasi kerja (x2) secara parsial terhadap kinerja (Y) karyawan PDAM Tirta Randik Sekayu. 
3. Pengaruh Lingkungan Kerja (x3) terhadap Kinerja (Y)

Nilai thitung untuk variabel lingkungan kerja (x3) terhadap kinerja (Y) adalah sebesar 4,637, maka thitung $(4,637)>$ ttabel $(1,993)$ yang berarti bahwa ada pengaruh lingkungan kerja (x2) secara parsial terhadap kinerja (Y) karyawan PDAM Tirta Randik Sekayu, maka H0 ditolak dan Ha diterima.

Nilai signifikan (Sig t) pengaruh lingkungan kerja (x3) secara parsial terhadap kinerja (Y) adalah sebesar 0,000 yang berarti Sig $\mathrm{t}(0,000)<\alpha(0,05)$. Hal tersebut berarti bahwa ada pengaruh yang signifikan lingkungan kerja (x3) secara parsial terhadap kinerja (Y) karyawan PDAM Tirta Randik Sekayu.

\section{$\underline{\text { Pembahasan }}$}

1. Pengaruh Kompetensi (x1), Motivasi (x2) dan Lingkungan Kerja (x3) secara Bersama-sama terhadap Kinerja (Y)

Berdasarkan pada uji hipotesis $\mathrm{F}$ dihasilkan nilai Fhitung untuk variabel kompetensi (x1), motivasi (x2) dan lingkungan kerja (x3) terhadap kinerja (Y) adalah sebesar 45,776, maka Fhitung $(45,776)>$ Ftabel $(2,732)$ dan nilai signifikan (Sig F) adalah sebesar 0,000 yang berarti Sig F $(0,000)<\alpha$ $(0,05)$. Hal tersebut berarti bahwa ada pengaruh yang positif dan signifikan kompetensi (x1), motivasi (x2) dan lingkungan kerja (x3) secara bersama-sama terhadap kinerja (Y) karyawan PDAM Tirta Randik
Sekayu, sehingga H0 ditolak dan $\mathrm{Ha}$ diterima.

Dari hasil perhitungan tersebut di atas, menggambarkan bahwa pada dasarnya variabel bebas yang penulis gunakan dalam penelitian ini, yaitu variabel kompetensi, motivasi dan lingkungan kerja memberikan dampak yang cukup besar terhadap kinerja karyawan PDAM Tirta Randik Sekayu.

Direktur PDAM Tirta Randik Sekayu Kabupaten Musi Banyuasin harus memperhatikan variabel kompetensi, motivasi dan lingkungan kerja dalam rangka meningkatkan kinerja para karyawannya, terutama pada sebagian kecil karyawan yang belum memiliki motivasi yang baik dan kompetensi yang belum memadai.

Namun di balik itu semua, dari hasil perhitungan determinasi, yaitu sebesar $65,6 \%$ yang berarti masih ada sisa sebesar 34,4\%. Hal ini menggambarkan bahwa masih ada faktor-faktor lain yang mempengaruhi kinerja karyawan PDAM Tirta Randik Sekayu, yaitu sebesar 34,4\%. Dalam kesempatan penelitian ini, penulis melakukan analisis terhadap 3 variabel, yaitu kompetensi, motivasi dan lingkungan kerja.

Keterkaitan antara kompetensi, motivasi dan lingkungan kerja dan kinerja, yaitu jika karyawan memiliki kompetensi yang memadai, memiliki motivasi yang tinggi dalam bekerja dan mempunyai lingkungan kerja yang baik, maka akan mudah bagi karyawan yang bersangkutan untuk berprestasi, yang pada akhirnya dapat meningkatkan kinerja perusahaan itu sendiri, 
sehingga tujuan yang diharapkan dapat tercapai.

2. Pengaruh Kompetensi (x1) secara Parsial terhadap Kinerja (Y)

Berdasarkan hasil pengolahan data dengan menggunakan SPSS for Windows versi 17.00 , diperoleh nilai koefisien regresi kompetensi terhadap kinerja adalah sebesar 0,091 $(9,1 \%)$ yang berarti bahwa kompetensi berpengaruh terhadap kinerja sebesar $9,1 \%$.

Nilai thitung adalah sebesar 0,734 , maka thitung $(0,734)<$ ttabel $(1,993)$ dan nilai signifikan (Sig t) sebesar 0,465 yang berarti Sig t $(0,465)>\alpha(0,05)$. Hal tersebut berarti bahwa kompetensi (x1) secara parsial tidak berpengaruh secara signifikan terhadap kinerja (Y), sehingga $\mathrm{H} 0$ diterima dan Ha ditolak. Dari hasil perhitungan tersebut menggambarkan bahwa kompetensi tidak memberikan kontribusi yang cukup dalam mempengaruhi kinerja karyawan PDAM Tirta Randik Sekayu. Hal ini menggambarkan bahwa kompetensi tidak berpengaruh secara signifikan kinerja karyawan.

Hasil pengamatan di lapangan menggambarkan bahwa kompetensi karyawan PDAM Tirta Randik Sekayu tidaklah rendah, namun justru cukup tinggi. Sebaliknya, hasil kerja karyawan atau kinerjanya cukup tinggi, sehingga hal ini mungkin salah satu gambaran yang menjelaskan ketiadaan pengaruh kompetensi terhadap kinerja.

Idealnya seorang karyawan harus memiliki kompetensi di dalam bekerja. Karyawan hendaknya memiliki kemampuan yang dilandasi oleh pengetahuan, keterampilan dan didukung oleh sikap yang dituntut dalam melaksanakan tugasnya.

Untuk dapat meningkatkan kompetensi karyawan, bukan hanya terletak pada karyawan itu sendiri, tetapi juga ada peran pimpinan di dalam memberikan kesempatan kepada karyawannya untuk mengembangkan kompetensinya, misalnya dengan memberi kesempatan untuk mengikuti pelatihan, memberi kesempatan untuk melanjutkan pendidikan ke jenjang yang lebih tinggi serta menyediakan media yang dapat menunjang dalam pengembangan kompetensi karyawan. Dengan demikian, diharapkan dapat tercipta karyawan yang professional yang memiliki kompetensi dan keahlian khusus serta keterampilan teoritik dan praktik dalam bekerja.

3. Pengaruh Motivasi (x2) secara Parsial terhadap Kinerja (Y)

Berdasarkan hasil pengolahan data dengan menggunakan SPSS for Windows versi 17.00 , diperoleh nilai koefisien regresi motivasi terhadap kinerja adalah sebesar 0,217 (21,7\%) yang berarti bahwa motivasi berpengaruh positif terhadap kinerja sebesar $21,7 \%$.

Nilai thitung adalah sebesar 2,743 , maka thitung $(2,743)>$ ttabel $(1,993)$ dan nilai signifikan (Sig t) sebesar 0,008 yang berarti Sig t $(0,008)<\alpha(0,05)$. Hal tersebut berarti bahwa ada pengaruh yang positif dan signifikan motivasi (x1) secara parsial terhadap kinerja (Y), sehingga $\mathrm{HO}$ ditolak dan Ha diterima.

Dari hasil perhitungan tersebut menggambarkan bahwa 
motivasi memberikan kontribusi yang cukup besar terhadap kinerja karyawan PDAM Tirta Randik Sekayu. Hal ini menggambarkan bahwa motivasi mempengaruhi kinerja karyawan. Hal ini dapat dimaklumi karena motivasi memberikan dampak yang besar terhadap pencapaian kinerja. Jika motivasi kerja karyawan tinggi, maka dapat dipastikan perusahaan dapat berkembang dan dapat meningkatkan produktivitas kerja karyawan, sebaliknya jika motivasi kerja karyawan rendah, maka perusahaan akan mengalami banyak masalah. Peningkatan motivasi kerja karyawan, pada akhirnya dapat meningkatkan kinerja karyawan tersebut, sehingga muaranya adalah kualitas kerja dan pelayanan publik, meningkatnya efisien dan efektivitas kerja, meningkatnya mutu sumber daya manusia serta timbulnya budaya kerja yang kreatif, produktif, profesional, bertanggungjawab dan meningkatnya daya saing.

Idealnya memang karyawan seharusnya termotivasi di dalam menjalankan tugas dan fungsinya. Hal ini dikarenakan karyawan tersebut sudah mendapatkan gaji yang sangat memadai. Pada dasarnya karyawan tersebut sudah tidak punya alasan lagi untuk tidak menjalankan tugas dan fungsinya.

Namun pada kenyataannya, karyawan PDAM Tirta Randik Sekayu relatif belum termotivasi dalam menjalankan tugas dan fungsinya. Secara individual hanya beberapa orang saja dari karyawan tersebut yang giat bekerja. Hal ini terlihat dari adanya karyawan yang terlambat, tidak bekerja tanpa alasan yang jelas, kurang memiliki perusahaan tempatnya bertugas, lebih banyak ngobrol atau melakukan kegiatan yang tidak produktif lainnya. Jadi karyawan PDAM Tirta Randik Sekayu belum memiliki motivasi yang tinggi dalam menjalankan tugasnya, terkesan bahwa mereka hanya cenderung rajin apabila menjelang akhir bulan saja karena sudah mendekati pembagian gaji, kemudian tingkat kerajinan mereka hanya berlanjut beberapa hari setelah hari pembagian gaji, selebihnya mereka terkesan bekerja dengan motivasi yang rendah.

Jika hal ini berlangsung terus-menerus, akan sulit bagi karyawan yang bersangkutan untuk mencapai tingkat kinerjanya yang optimal. Rendahnya motivasi kerja segelintir karyawan tersebut, tentunya akan berdampak buruk terhadap motivasi kerja keseluruhan karyawan dalam perusahaan.

Direktur hendaknya mencari tahu apa yang menjadi penyebab rendahnya motivasi karyawannya. Apakah kompensasi yang mereka terima tidak dapat mencukupi kebutuhan hidup mereka atau ada permasalahan lain. Jika permasalahannya adalah kompensasi, maka sulit bagi pimpinan untuk menyelesaikannya karena kompensasi yang karyawan terima, terutama dalam bentuk gaji, tidak bisa dinaikkan oleh pimpinan karena gaji yang diterima oleh karyawan tersebut adalah standar gaji yang telah diatur oleh perusahaan. Oleh karena itu, pimpinan harus mampu mencarikan jalan keluar untuk dapat mensejahterakan karyawannya. 
4. Pengaruh Lingkungan Kerja (x3) secara Parsial terhadap Kinerja (Y)

Berdasarkan hasil pengolahan data dengan menggunakan SPSS for Windows versi 17.00, diperoleh nilai koefisien regresi lingkungan kerja terhadap kinerja adalah sebesar 0,496 $(49,6 \%)$ yang berarti bahwa lingkungan kerja berpengaruh positif terhadap kinerja sebesar 49,6\%.

Nilai thitung adalah sebesar 4,637, maka thitung $(4,637)>$ ttabel $(1,993)$ dan nilai signifikan (Sig t) sebesar 0,000 yang berarti Sig $t$ $(0,000)<\alpha(0,05)$. Hal tersebut berarti bahwa ada pengaruh yang positif dan signifikan lingkungan kerja (x3) secara parsial terhadap kinerja (Y), sehingga $\mathrm{H} 0$ ditolak dan Ha diterima.

Dari hasil perhitungan tersebut menggambarkan bahwa lingkungan kerja memberikan kontribusi yang besar terhadap kinerja karyawan PDAM Tirta Randik Sekayu. Hal ini menggambarkan bahwa lingkungan kerja mempengaruhi kinerja karyawan.

Hal ini dapat dimaklumi karena lingkungan kerja memberikan dampak yang besar terhadap pencapaian kinerja. Jika lingkungan kerja karyawan baik, maka dapat dipastikan perusahaan dapat berkembang dan dapat meningkatkan produktivitas kerja karyawan, sebaliknya jika lingkungan kerja karyawan yang tidak memadai, maka akan dapat menurunkan kinerja dan akhirnya menurunkan motivasi kerja karyawan.

Idealnya memang lingkungan kerja harus mampu mendukung karyawan dalam melaksanakan kegiatan secara optimal, sehat, aman dan nyaman, tidak bising, terang dan bebas dari segala macam ancaman dan gangguan yang dapat menghambat kinerja karyawan.

Namun pada kenyataannya, lingkungan kerja PDAM Tirta Randik Sekayu masih kurang baik. Hal ini terlihat dari penerangan yang kurang baik, ventilasi udara yang kurang baik, tata warna lingkungan kerja yang kurang tepat, kebisingan yang akibat perusahaan yang berbatasan langsung dengan jalan lintas, tata ruang kerja yang kurang baik, tidak berimbangnya perhatian pihak perusahaan terhadap karyawannya.

Direktur selaku pimpinan perusahaan harus mampu menciptakan lingkungan kerja yang baik karena keberhasilan perusahaan dalam mencapai tujuan tidak terlepas dari faktor lingkungan kerja, baik fisik maupun non fisik/psikologis. Lingkungan kerja yang baik akan menunjang karyawan dalam mencapai kinerja yang optimal.

\section{KESIMPULAN}

Berdasarkan hasil penelitian dan pembahasan sebelumnya, dapat penulis simpulkan bahwa penelitian ini membuktikan secara empiris tentang pengaruh kompetensi, motivasi dan lingkungan kerja terhadap kinerja karyawan PDAM Tirta Randik Sekayu Kabupaten Musi Banyuasin :

1. Kompetensi, motivasi dan lingkungan kerja secara bersamasama berpengaruh positif dan signifikan terhadap kinerja karyawan PDAM Tirta Randik 
Sekayu Kabupaten Musi Banyuasin.

2. Kompetensi tidak berpengaruh secara signifikan terhadap kinerja karyawan PDAM Tirta Randik Sekayu Kabupaten Musi Banyuasin.

3. Motivasi berpengaruh positif dan signifikan terhadap kinerja karyawan PDAM Tirta Randik Sekayu Kabupaten Musi Banyuasin.

4. Lingkungan kerja berpengaruh positif dan signifikan terhadap kinerja karyawan PDAM Tirta Randik Sekayu Kabupaten Musi Banyuasin.

\section{SARAN}

Berdasarkan simpulan di atas, maka penulis memberikan saran sebagai berikut:

1. Direktur perlu untuk meningkatkan komunikasi kepada karyawan secara langsung dan tatap muka, sehingga terjalin kerjasama yang optimal dalam pencapaian tujuan perusahaan.

2. Direktur hendaknya mengevaluasi kembali kinerja karyawannya, sehingga dapat menimbulkan perilaku yang positif sesuai dengan etos kerja yang diharapkan. Untuk itu, perlu diperhatikan faktor-faktor internal dan eksternal yang menunjang sarana dan prasarana kerja termasuk keteladanan dan manajerial. Hal yang tidak kalah pentingnya adalah memberikan reward dan punishment bagi karyawan secara terukur dan adil.

3. Direktur hendaknya memberikan perhatian lebih terhadap lingkungan kerja non fisik karena lingkungan kerja non fisik dalam suatu organisasi akan menciptakan suasana yang kondusif, sehingga mempengaruhi kinerja karyawan. Lingkungan kerja non fisik yang penulis maksudkan antara lain hubungan antar sesama rekan kerja maupun dengan pimpinan perusahaan. Hal yang tidak kalah pentingnya adalah pemanfaatan secara optimal fasilitas fisik yang ada, sehingga akan mampu meningkatkan kinerja karyawan. Direktur perlu mengupayakan perbaikan dan melengkapi sarana dan prasarana yang telah ada.

\section{DAFTAR PUSTAKA}

Agus Ahyari. 2002. Manajemen Produksi dan Pengendalian Produksi. Yogyakarta: BPFE.

Anwar Prabu Mangkunegara. 2009. Perencanaan dan Pengembangan Sumber Daya Manusia. Bandung: PT. Refika Aditama.

Duwi Priyatno. 2010. Mandiri Belajar SPSS. Yogyakarta: MediaKom.

Handoko Martin. 2003. Motivasi Daya Penggerakan Tingkah Laku. Jakarta: PT. Rineka Cipta.

Robbins, Stephen P. 2001. Prinsipprinsip Perilaku Organisasi, Edisi Kelima. Alih Bahasa Halida dan Dewi Sartika. 2002. Jakarta: Erlangga.

Robbins, Stephen P dan Mary Coulter. 
2009.Manajemen, Edisi Kesepuluh. Alih Bahasa Bob Sabran dan Devri Barnadi Putera. 2010. Jakarta: Erlangga.

Sekaran, Uma. 2006. Research Methods for Business, Metodologi Penelitian untuk Bisnis. Jakarta: Salemba Empat.

Sugiarto dkk. 2003. Teknik Sampling. Jakarta: PT. Gramedia Pustaka Utama.

Veithzal Rivai dan Ella Jauvani Sagala. 2010. Manajemen Sumber Daya Manusia untuk Wibowo. 2011. Manajemen Kinerja. Jakarta: Rajawali Pers
Rusdy A. Rifai. 2009. Manajemen Cetakan Kedua Edisi 2. Palembang: Lembaga Penerbit FE UM Sugiyono. 2007. Metode Penelitian Bisnis. Bandung: CV. Alfabeta.

T. Hani Handoko. 2003. Manajemen. Yogyakarta: BPFE. 
